\title{
A Study Regarding the Correlations that Exist between Types of Cultures in Banking Organizations and the Country of Origin of the Majority Capital, the Gender of the Employees, their Age, Level of Experience and Seniority the Organization
}

\author{
Cosmin MATIS ${ }^{\star}$
}

\begin{tabular}{l}
\hline \multicolumn{1}{c}{ A R T I C L E I N F O } \\
\hline Article history: \\
Accepted March 2020 \\
Available online May 2020 \\
\hline JEL Classification \\
G20, G24 \\
Keywords: \\
Types of cultures, Task Type, \\
Power Type, Role Type, Person \\
Type, ANOVA analysis, Variables, \\
Country of origin of capital, Gender \\
of employees, Level of experience, \\
seniority in organization, Age
\end{tabular}

1. Introduction

The organizational culture in the banking system represents one of the important concepts that has affirmed itself relatively recently and that has significantly influenced the mode of thinking and action of the employees, determining important changes within organizations after the privatization process. The organizational culture of the foreign banks that took over the leadership of the subsidiaries in Romania leaves its mark on the autochthonous types og organizational cultures through the values promoted and the strategies implemented. The structuring of the employees according to age, level of experience, and seniority in the organization influences the type of organizational culture that is shaping in banks in Romania. The members of banking organizations increasingly emphasize systems of values, knowledge and behavior in order to adapt the elements of the national culture to the character of the organizational culture from the institution of which they are an integral part. Through the values displayed and the actions undertaken, the organizational culture determines changes that are of a certain depth, in the manner of perception, thinking and action of those who are a part of it.

Starting from the literature in this field it is worth mentioning Lynch's (2002, p.320) scientific endeavor to analyze organizational culture through the prism of certain groups of elements, namely: cultural factors specific to the organization, the environment, cultural styles that are fundamental to the organization and the analysis of strategic implications, and we can show that in each banking organization we encounter their own set of beliefs, values, and organizational cultures that are reflected in their structure as well as in the elaboration of strategies regarding the economic environment in which it is developing and which is dominated by continuous competition and change.

The importance of analyzing the organizational culture is also given by the practical valences that are presented by this variable that is increasingly used, in enhancing the performance of the organization. Peters

\begin{abstract}
The aim of this article is that of establishing the correlations that exist between the types of the organization of the respondents in banking organizations in Romania by using the questionnaire that was used in order to create the database needed for the analysis.
Through the ANOVA analysis of the correlations that exist between the four types of organizational cultures (Task Type, Power Type, Role Type and Person Type) and of the aforementioned variables we can conclude that for both the operating personnel and for organizational culture in the Romanian banking system, while the age and seniority in the experience in the banking system does not manifest itself as a variable with a significant impact on organizational cultures, with the exceptions of the banks in which the Role Type
culture is predominant and in which the managers are aware of the importance of the experience accumulated in the field. In regards to the gender, this leaves its mark on the of the Task
\end{abstract}

(C) 2020 EAI. All rights reserved. 
and Waterman (1982) offer a strong argument through studies conducted in successful companies, showing that the top performers create a wide, shared culture, a coherent framework in which people search for an appropriate adaptation.

Another opinion that stood at the basis of the present study was that of Hofstede (Hofstede et al., 2012, p. 239), according to whom in long-term oriented organizations the emphasis is on prudence in spending resources, but also on availability towards investments and innovation, as well as on perseverance in obtaining the results. In the case of short-term oriented organization there is a respect that is manifested towards traditions and social responsibilities, pursuing immediate results.

Other empirical research has shown the substantial impact of cultural variables and their effects are the ones developed by Zhenget al. (2012). By using Hofstede's four cultural dimensions (uncertainty avoidance, collectivism, power distance and masculinity) as a model of analysis for the culture of a country and by using a sample of 114.723 respondents from forty countries during the 1991-2006 period, the authors document the fact that the companies found in countries with a high level of uncertainty avoidance, high collectivism, wide distance regarding power and high masculinity, tend to use short-term debt more (Cristache et al, 2019).

Moreover, we took into account Handy's (1985) research that, starting from the four types of cultures, associates two of them, namely the Role Type culture and the Person Type culture with stability and reticence towards change, while the other two types (the Task Type culture and the Power Type one) are associated with flexibility and adaptability to change. Thus, the last two types of organizational cultures are promoters of change and they very quickly implement the changes they go through.

It is worth mentioning the opinion of Schein (1985), which shows the need for an interpretation of organizational behaviors. Therefore, in order to understand the behaviors of their members, certain patterns can be of real use.

Another research that was at the basis of this study is that developed by Marcoulidesand Heck (1993). The emphasis is on identifying the stages and the internal mechanisms, on the dynamics of the functionality and less on categorizing and hierarchizing culture typologies. The authors try to explain the manner in which organizational culture influences the performance of the organization. In their view, organizational culture is seen as being the expression of three interconnected dimensions: a socio-cultural system of the manner in which the functioning of organizational strategies and practices is perceived; a system of organizational values; and the collective beliefs of the individuals who work in the organization.

\section{Research methodology}

For this study we have used as a research instrument the questionnaire given to 410 employees from the banking system, of which 150 were managers and 260 were operating personnel.

The selection of these was exhaustively done, limited by their level of involvement, an approval being needed from those who run the organizations.

The method of gathering data was by directly administering the questionnaires at banking unites as well as the indirect method, through an electronic format and communication channel.

The applied questionnaire was a mixed one, including both open ended and closed ended questions, as well as control questions. In addition, it includes dichotomousquestions (with YES or NO answers), open ended questions that allow for answers of an unspecified length, multiple-choice questions, also called semiopen ended (a limited number of given answers), scaling responses, also called questions with ranked answers within a hierarchy (the Likert scale - through which individual preferences can be tested gradually).

Then we studied, by applying the ANOVA method, the correlation that exists between the types of cultures and elements such as: country of origin of the majority capital, gender, age, level of experience within the banking system and years spent within the organization.

In addition, we utilized graphical representation of the correlation that exists between the types of cultures and the answers of the respondents based on the country of origin of the majority capital (both from the point of view of managers as well as that of operational personnel).

\section{Analysis of the corellation between the types of organizational cultures and the variables considered in the present research}

In order to determine the correlation that exists between the types of cultures and variables: country of origin of the majority capital, the gender of the respondents, age, level of professional experience within the banking system and the years spent within the organization in which they carry out their activities at the time of the completion of the questionnaires we used the ANOVA analysis

(1) Exemplifying the research methodology with respect to employees in leadership positions 
a) The Variable - Country of origin for the majority capital

Average

\begin{tabular}{|l|c|r|r|r|}
\hline $\begin{array}{l}\text { Country of origin for the } \\
\text { majority capital }\end{array}$ & \multicolumn{1}{c|}{ Tasks } & \multicolumn{1}{c|}{ Role } & \multicolumn{1}{c|}{ Power } & \multicolumn{1}{c|}{ Person } \\
\hline Romania & .5761103 & .4147000 & .6476217 & .2287309 \\
Austria & -.3014700 & -.4950630 & -.1779873 & -.1974553 \\
France & .2697787 & .2854498 & .3110738 & .3369486 \\
Italy & -.8561594 & -.1177382 & -1.1400054 & -.6609513 \\
Holland & .2824380 & -.1267738 & .7319236 & .5361175 \\
Greece & -.6223154 & -.2290135 & -.3335525 & -.2527838 \\
Hungary & .3465235 & -.1481129 & .3237570 & .2951008 \\
Other countries & .1768722 & .1167086 & -.3338992 & -.0982143 \\
Total & .0000000 & .0000000 & .0000000 & .0000000 \\
\hline
\end{tabular}

ANOVA Table

\begin{tabular}{|c|c|c|c|c|c|c|}
\hline & & Sum of Squares & Df & $\begin{array}{c}\text { Mean } \\
\text { Square }\end{array}$ & $\mathrm{F}$ & Sig. \\
\hline \multirow{3}{*}{$\begin{array}{l}\text { Tasks * Country of } \\
\text { origin for the majority } \\
\text { capital }\end{array}$} & $\begin{array}{l}\text { Between } \\
\text { Groups }\end{array}$ & 32.679 & 7 & 4.668 & 5.708 & .000 \\
\hline & Within Groups & 115.321 & 141 & .818 & & \\
\hline & Total & 148.000 & 149 & & & \\
\hline \multirow{3}{*}{$\begin{array}{l}\text { Role* Country of } \\
\text { origin for the majority } \\
\text { capital }\end{array}$} & $\begin{array}{l}\text { Between } \\
\text { Groups }\end{array}$ & 13.632 & 7 & 1.947 & 2.043 & .054 \\
\hline & Within Groups & 135.368 & 142 & .953 & & \\
\hline & Total & 149.000 & 149 & & & \\
\hline \multirow{3}{*}{$\begin{array}{l}\text { Power * Country of } \\
\text { origin for the majority } \\
\text { capital }\end{array}$} & $\begin{array}{l}\text { Between } \\
\text { Groups }\end{array}$ & 40.650 & 7 & 5.807 & 7.611 & .000 \\
\hline & Within Groups & 108.350 & 142 & .763 & & \\
\hline & Total & 149.000 & 149 & & & \\
\hline \multirow{3}{*}{$\begin{array}{l}\text { Person * Country of } \\
\text { origin for the majority } \\
\text { capital }\end{array}$} & $\begin{array}{l}\text { Between } \\
\text { Groups }\end{array}$ & 14.658 & 7 & 2.094 & 2.213 & .037 \\
\hline & Within Groups & 134.342 & 142 & .946 & & \\
\hline & Total & 149.000 & 149 & & & \\
\hline
\end{tabular}

\section{All variables are significant, Sig.<0.1}

The conclusions that result from the application of the ANOVA analysis in relation to the variablecountry of origin of the majority capital:

- Regardless of the types of cultures found within the banking organization, it differs significantly depending on the country of origin of the majority capital;

- The managers of banking organizations with national and French majority capital tend on average to Agree, while those with Austrian, Greek and Italian majority capital tend on average to Disagree.

The correlations that exist between the types of cultures and the answers given by the respondents persons in leadership positions depending on the country of origin of the majority capital are illustrated also in the following graphical representations: 
Graph1. Opinion of managers regarding the types of cultures that are predominant in the banking organizations that they are active in based on country of origin for the majority capital

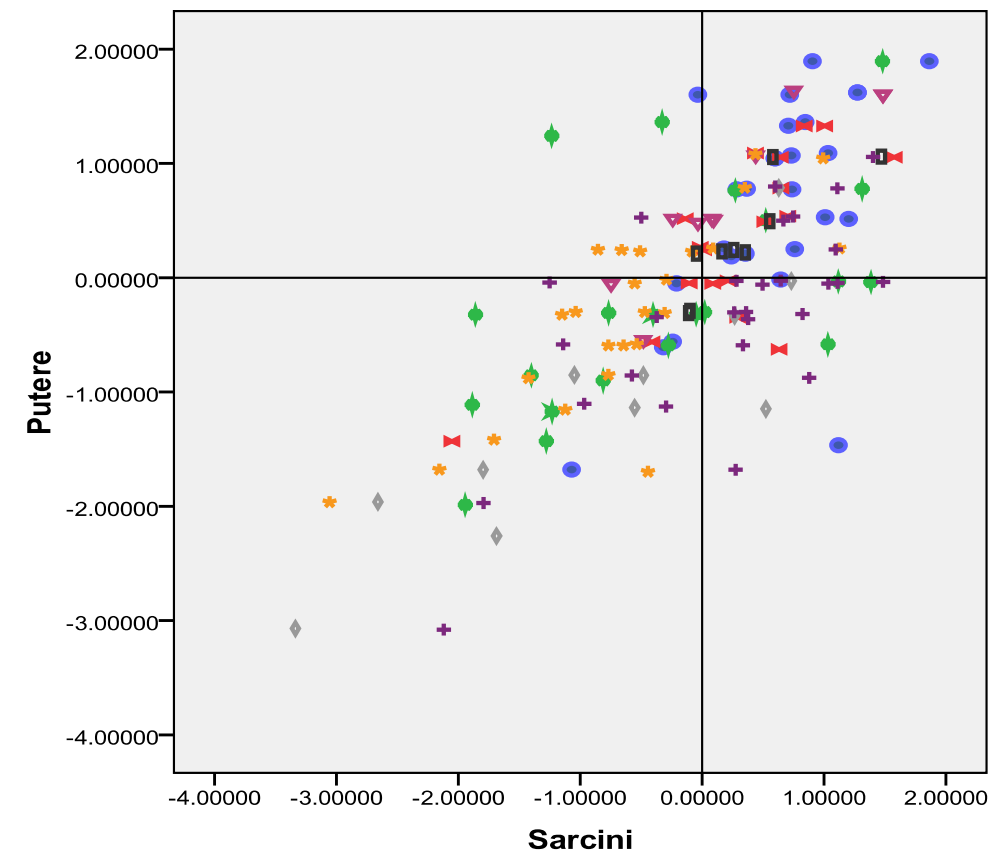

Tara de provenienta a capitalului majoritar

Romania

Austria

Aranta

$\checkmark$ Italia

$\nabla$ Olanda

* Grecia

Ungaria

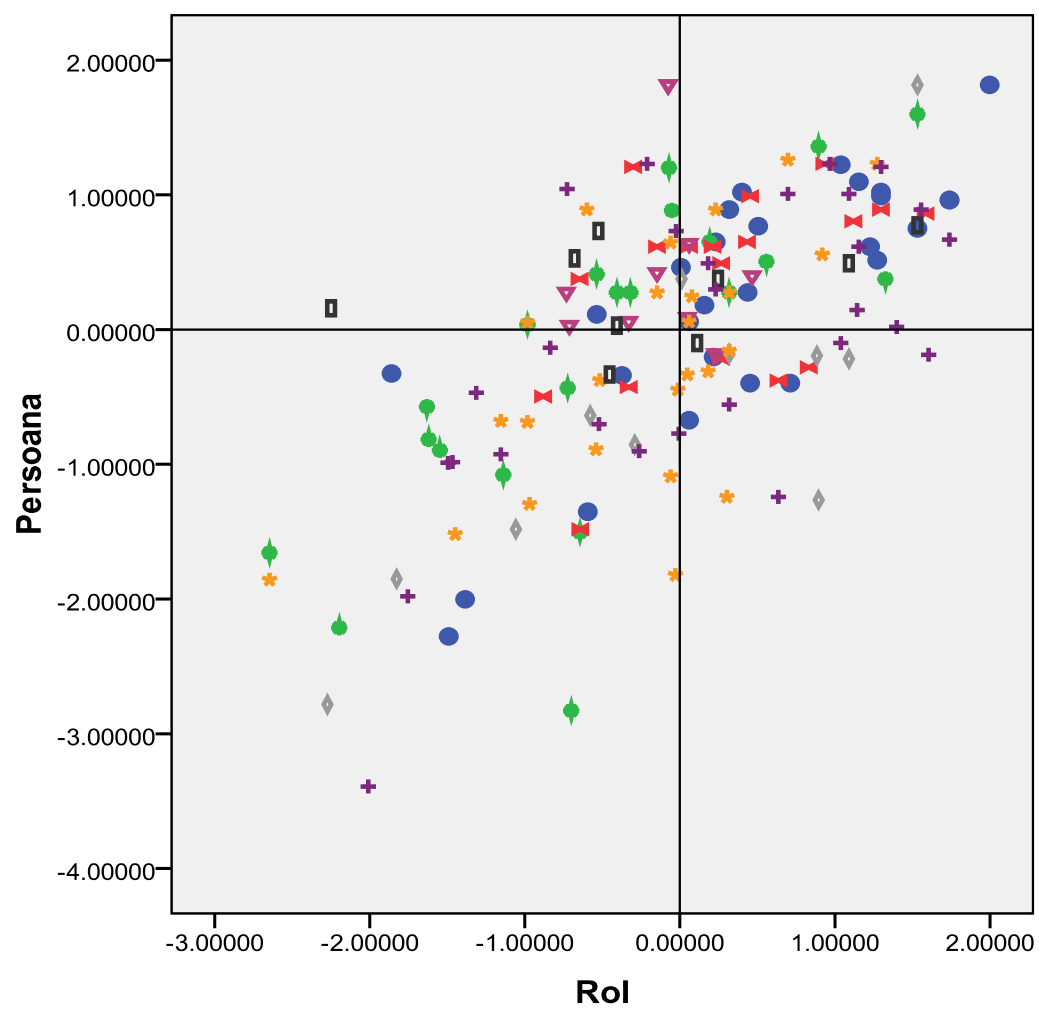

Tara de provenienta a capitalului majoritar

Romania

Austria

A Franta

Italia

$\nabla$ Olanda

* Grecia

Ungaria

+ Alte tari

Source: Author's projection 
Average

\begin{tabular}{|l|r|r|r|r|}
\hline $\begin{array}{l}\text { Country of origin for } \\
\text { the majority capital }\end{array}$ & \multicolumn{1}{|c|}{ Tasks } & \multicolumn{1}{c|}{ Power } & \multicolumn{1}{c|}{ Role } & \multicolumn{1}{c|}{ Person } \\
\hline Romania & -.0741938 & .0906397 & -.0265744 & -.2303358 \\
Austria & .0302831 & .1060312 & -.0776530 & -.0061098 \\
France & .3238371 & .4982439 & .4978419 & .4151304 \\
Italy & -.5728492 & -.6089915 & -.5552521 & -.6432648 \\
Holland & -.1561222 & .2050079 & .1418108 & .3241771 \\
Greece & -.2050772 & -.4249046 & -.2831445 & -.1153835 \\
Hungary & .5379341 & .4391938 & .2255276 & .5796466 \\
Other countries & .0200557 & -.2151480 & .1779748 & -.0911289 \\
Total & .0000000 & .0000000 & .0000000 & .0000000 \\
\hline
\end{tabular}

ANOVA Table

\begin{tabular}{|c|c|c|c|c|c|c|}
\hline & & Sum of Squares & df & Mean Square & $\mathrm{F}$ & Sig. \\
\hline \multirow{3}{*}{$\begin{array}{l}\text { Tasks * Country of } \\
\text { origin for the majority } \\
\text { capital }\end{array}$} & Between Groups & 23.224 & 7 & 3.318 & \multirow[t]{3}{*}{3.546} & \multirow[t]{3}{*}{.001} \\
\hline & Within Groups & 235.776 & 252 & .936 & & \\
\hline & Total & 259.000 & 259 & & & \\
\hline \multirow{3}{*}{$\begin{array}{l}\text { Role * Country of origin } \\
\text { for the majority capital }\end{array}$} & Between Groups & 32.873 & 7 & 4.696 & \multirow[t]{3}{*}{5.233} & \multirow[t]{3}{*}{.000} \\
\hline & Within Groups & 226.127 & 252 & .897 & & \\
\hline & Total & 259.000 & 259 & & & \\
\hline \multirow{3}{*}{$\begin{array}{l}\text { Power * Country of } \\
\text { origin for the majority } \\
\text { capital }\end{array}$} & Between Groups & 22.447 & 7 & 3.207 & \multirow[t]{3}{*}{3.416} & \multirow[t]{3}{*}{.002} \\
\hline & Within Groups & 236.553 & 252 & .939 & & \\
\hline & Total & 259.000 & 259 & & & \\
\hline \multirow{3}{*}{$\begin{array}{l}\text { Person * Country of } \\
\text { origin for the majority } \\
\text { capital }\end{array}$} & Between Groups & 31.169 & 7 & 4.453 & \multirow[t]{3}{*}{4.925} & \multirow[t]{3}{*}{.000} \\
\hline & Within Groups & 227.831 & 252 & .904 & & \\
\hline & Total & 259.000 & 259 & & & \\
\hline
\end{tabular}

All variables are significant with a significance level of $1 \%$

Graph 2. Opinion of operating personnel regarding the types of cultures that are predominant in the banking organizations that they are active in based on country of origin for the majority capital

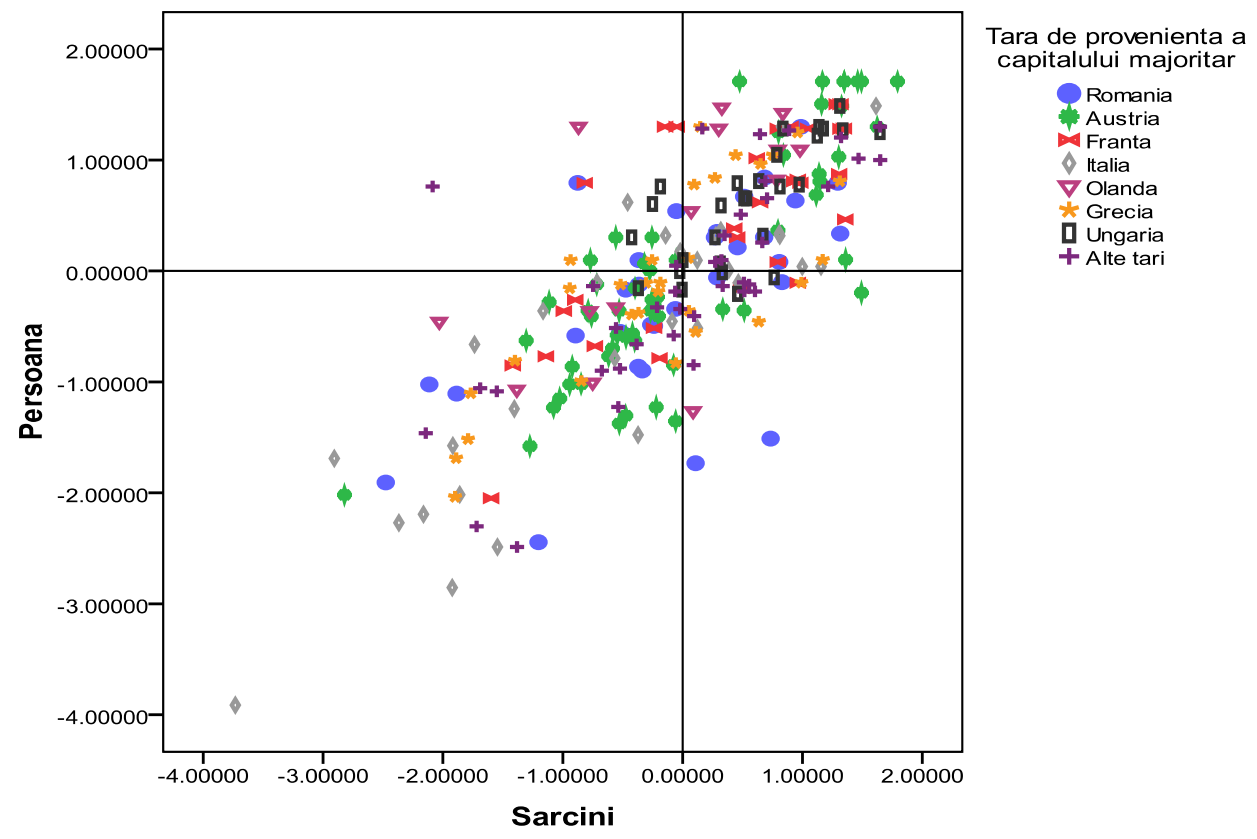




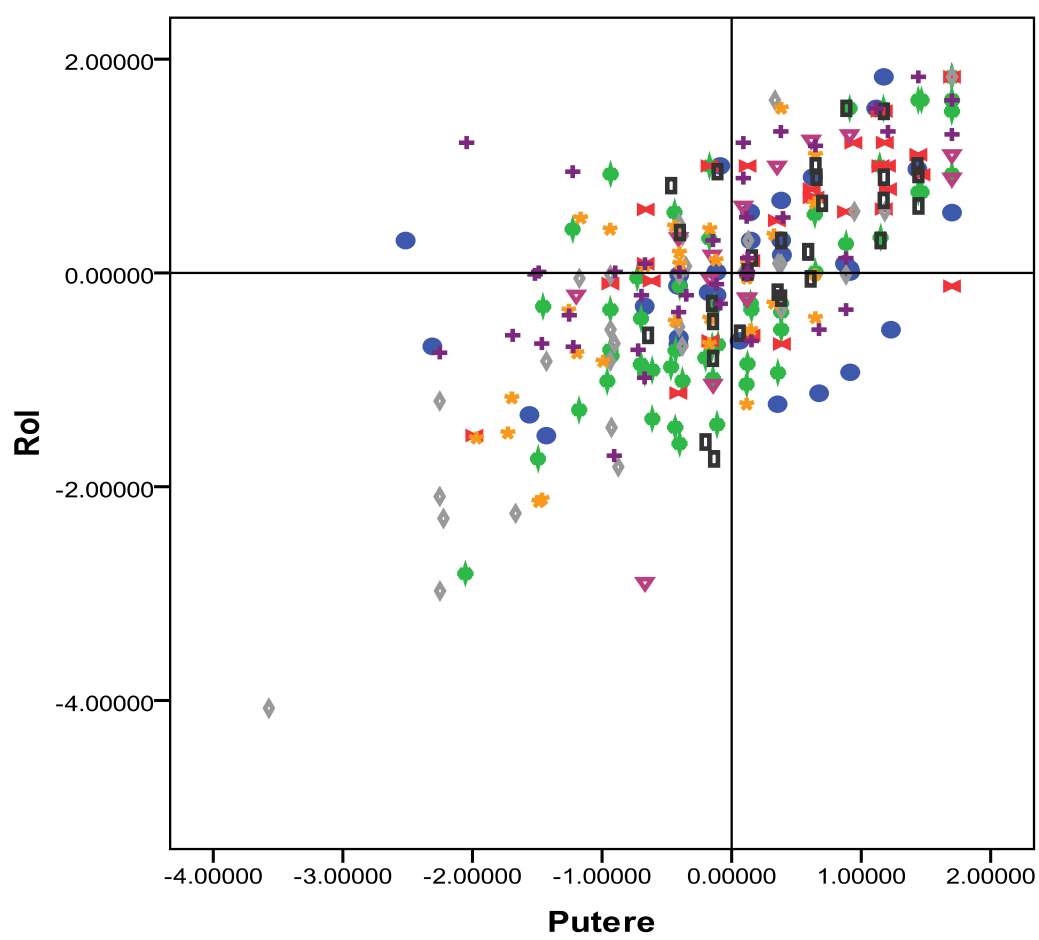

Tara de provenienta a capitalului majoritar

Romania

* Austria

4 Franta

$\checkmark$ Italia

$\nabla$ Olanda

* Grecia

U Ungaria

+ Alte tari

Source: Author's projection

b) Variable-gender of respondents

Average
\begin{tabular}{|l|c|c|c|c|}
\hline Gender & Tasks & \multicolumn{1}{c|}{ Role } & Power & \multicolumn{1}{l|}{ Person } \\
\hline Male & -.1744426 & -.1836426 & -.1460341 & -.0219023 \\
Female & .1277893 & .1329825 & .1057488 & .0158603 \\
Total & .0000000 & .0000000 & .0000000 & .0000000 \\
\hline
\end{tabular}

ANOVA Table

\begin{tabular}{|c|c|c|c|c|c|c|}
\hline & & Sum of Squares & Df & Mean Square & $\mathrm{F}$ & Sig. \\
\hline \multirow[t]{3}{*}{ Tasks * gender } & Between Groups & 3.321 & 1 & 3.321 & 3.375 & .068 \\
\hline & Within Groups & 144.679 & 147 & .984 & & \\
\hline & Total & 148.000 & 149 & & & \\
\hline \multirow[t]{3}{*}{ Role * gender } & Between Groups & 3.663 & 1 & 3.663 & 3.730 & .055 \\
\hline & Within Groups & 145.337 & 148 & .982 & & \\
\hline & Total & 149.000 & 149 & & & \\
\hline \multirow[t]{3}{*}{ Power* gender } & Between Groups & 2.316 & 1 & 2.316 & 2.337 & .128 \\
\hline & Within Groups & 146.684 & 148 & .991 & & \\
\hline & Total & 149.000 & 149 & & & \\
\hline \multirow[t]{3}{*}{ Person * gender } & Between Groups & .052 & 1 & .052 & .052 & .820 \\
\hline & Within Groups & 148.948 & 148 & 1.006 & & \\
\hline & Total & 149.000 & 149 & & & \\
\hline
\end{tabular}

Gender variables for the Task Type and Role Type Cultures are significant, Sig.<0.1

The conclusions that result from the application of the ANOVA analysis in relation to the variable gender or respondents:

- For the Task and Role Type organizational cultures significant differences exist based on the gender of employees in leadership positions;

- Female managers tend on average to Agree, unlike males, who tend on average to Disagree. 


\section{c) Variable-Age of respondents}

Average

\begin{tabular}{|l|r|r|r|r|}
\hline Age & \multicolumn{1}{|l|}{ Tasks } & \multicolumn{1}{l|}{ Role } & \multicolumn{1}{l|}{ Power } & \multicolumn{1}{l|}{ Person } \\
\hline $20-30$ years & -.1207217 & -.1221735 & -.0665546 & -.0831474 \\
$30-40$ years & -.0752536 & -.1332142 & -.0249861 & -.0712425 \\
$40-50$ years & .0468053 & .1451090 & .0046821 & -.0093663 \\
50 de years & .4401827 & .3778798 & .2348651 & .6295994 \\
Total & .0000000 & .0000000 & .0000000 & .0000000 \\
\hline
\end{tabular}

ANOVA Table

\begin{tabular}{|c|c|c|c|c|c|c|}
\hline & & Sum of Squares & Df & Mean Square & $\mathrm{F}$ & Sig. \\
\hline \multirow[t]{3}{*}{ Tasks * Age } & Between Groups & 2.869 & 3 & .956 & .956 & .416 \\
\hline & Within Groups & 145.131 & 145 & 1.001 & & \\
\hline & Total & 148.000 & 149 & & & \\
\hline \multirow[t]{3}{*}{ Role * Age } & Between Groups & 4.164 & 3 & 1.388 & 1.399 & .245 \\
\hline & Within Groups & 144.836 & 146 & .992 & & \\
\hline & Total & 149.000 & 149 & & & \\
\hline \multirow[t]{3}{*}{ Power * Age } & Between Groups & .720 & 3 & .240 & .236 & .871 \\
\hline & Within Groups & 148.280 & 146 & 1.016 & & \\
\hline & Total & 149.000 & 149 & & & \\
\hline \multirow[t]{3}{*}{ Person * Age } & Between Groups & 4.839 & 3 & 1.613 & 1.634 & .184 \\
\hline & Within Groups & 144.161 & 146 & .987 & & \\
\hline & Total & 149.000 & 149 & & & \\
\hline
\end{tabular}

\section{No variable is significant, Sig.>0.1}

The conclusions that result from the application of the ANOVA analysis in relation to the variable-age of respondents:

- Regardless of the types of cultures found within the banking organizations, no significant differences exist based on the age of employees in leadership positions;

- Managers with ages above 40 tend on average to Agree, they being interested in stability, while young managers, with ages below 40 , tend on average to Disagree, which explains their mobility.

d) Variable - Level of professional experience within the banking system Average

\begin{tabular}{|l|r|r|r|r|}
\hline $\begin{array}{c}\text { Your level of professional } \\
\text { experience within the banking } \\
\text { system: }\end{array}$ & Tasks & Role & Power & Person \\
\hline $0-5$ years & .1102980 & -.3095522 & .3552667 & -.4105976 \\
$5-10$ years & -.1273166 & -.2173692 & .0984224 & -.1455137 \\
$10-15$ years & -.0728364 & -.0157562 & -.1428261 & -.0023861 \\
$15-20$ years & .0987865 & -.0404353 & -.0090297 & .1493977 \\
Over 20 years & .2325430 & .5750893 & .0684686 & .1974156 \\
Total & .0000000 & .0000000 & .0000000 & .0000000 \\
\hline
\end{tabular}

ANOVA Table

\begin{tabular}{|ll|r|r|r|r|r|}
\hline & & Sum of Squares & Df & Mean Square & F & Sig. \\
\hline Tasks * Your level of & Between Groups & 2.466 & 4 & .616 & .610 & .656 \\
professional experience & Within Groups & 145.534 & 144 & 1.011 & & \\
within the banking & Total & 148.000 & 149 & & & \\
system: & Tor & & & \\
\hline
\end{tabular}




\begin{tabular}{|c|c|c|c|c|c|c|}
\hline $\begin{array}{l}\text { Role * Your level of } \\
\text { professional experience } \\
\text { within the banking } \\
\text { system: }\end{array}$ & $\begin{array}{l}\text { Between Groups } \\
\text { Within Groups } \\
\text { Total }\end{array}$ & $\begin{array}{r}9.850 \\
139.150 \\
149.000\end{array}$ & $\begin{array}{r}4 \\
145 \\
149\end{array}$ & $\begin{array}{r}2.463 \\
.960\end{array}$ & 2.566 & .041 \\
\hline $\begin{array}{l}\text { Power *Your level of } \\
\text { professional experience } \\
\text { within the banking } \\
\text { system: }\end{array}$ & $\begin{array}{l}\text { Between Groups } \\
\text { Within Groups } \\
\text { Total }\end{array}$ & $\begin{array}{r}2.448 \\
146.552 \\
149.000\end{array}$ & $\begin{array}{r}4 \\
145 \\
149\end{array}$ & $\begin{array}{r}.612 \\
1.011\end{array}$ & .606 & .659 \\
\hline $\begin{array}{l}\text { Person * Your level of } \\
\text { professional experience } \\
\text { within the banking } \\
\text { system: }\end{array}$ & $\begin{array}{l}\text { Between Groups ( } \\
\text { Within Groups } \\
\text { Total }\end{array}$ & $\begin{array}{r}3.511 \\
145.489 \\
149.000\end{array}$ & $\begin{array}{r}4 \\
145 \\
149\end{array}$ & \begin{tabular}{r|}
.878 \\
1.003
\end{tabular} & .875 & .481 \\
\hline
\end{tabular}

In the case of Role type culture, the Variable - Level of professional experience within the banking systemis significant, Sig. $<0.1$

The conclusions that result from the application of the ANOVA analysis in relation to the variable - professional experience within the banking system of the respondents:

- For Role Type organizational cultures there exist significant differences based on the level of professional experience within the banking system of the employees; if we consider the main principles of this type of culture - stable and organized environment, high degree of formality, standardized rules and procedures, it makes sense why the level of experience within the banking system is important;

- Managers with a professional experience of over 20 years within the banking system tend on average to Agree, while in the case of managers with a professional experience between 10-15 years within the banking system a feeling of disgruntlement can be felt and they tend on average to Disagree.

e) Variable - Years spent in current organization Average

\begin{tabular}{|l|r|r|r|r|}
\hline \multicolumn{1}{|c|}{$\begin{array}{c}\text { Years spent in current } \\
\text { organization }\end{array}$} & \multicolumn{1}{c|}{ Tasks } & \multicolumn{1}{c|}{ Role } & \multicolumn{1}{c|}{ Power } & \multicolumn{1}{c|}{ Person } \\
\hline $0-5$ years & -.1898169 & -.2557245 & -.1279295 & -.1954179 \\
$5-10$ years & -.0019546 & .0426976 & .0164962 & .0473137 \\
$10-15$ years & .3087432 & .1604744 & .1477383 & .1420731 \\
$15-20$ years & .0812697 & -.0501989 & .2361592 & .1924465 \\
Over 20 years & -.7766794 & .4468067 & -.8685637 & -.6395835 \\
Total & .0000000 & .0000000 & .0000000 & .0000000 \\
\hline
\end{tabular}

ANOVA Table

\begin{tabular}{|c|c|c|c|c|c|c|}
\hline & & Sum of Squares & Df & Mean Square & $\mathrm{F}$ & Sig. \\
\hline \multirow{3}{*}{$\begin{array}{l}\text { Tasks * Years spent in } \\
\text { current organization }\end{array}$} & Between Groups & 6.636 & 4 & \multirow{3}{*}{$\begin{array}{r}1.659 \\
.982\end{array}$} & \multirow[t]{3}{*}{1.690} & \multirow[t]{3}{*}{.155} \\
\hline & Within Groups & 141.364 & 144 & & & \\
\hline & Total & 148.000 & 149 & & & \\
\hline \multirow{3}{*}{$\begin{array}{l}\text { Role * Years spent in } \\
\text { current organization }\end{array}$} & Between Groups & 4.102 & 4 & \multirow{3}{*}{$\begin{array}{r}1.026 \\
.999\end{array}$} & \multirow[t]{3}{*}{1.026} & \multirow[t]{3}{*}{.396} \\
\hline & Within Groups & 144.898 & 145 & & & \\
\hline & Total & 149.000 & 149 & & & \\
\hline \multirow{3}{*}{$\begin{array}{l}\text { Power * Years spent in } \\
\text { current organization }\end{array}$} & Between Groups & 4.860 & 4 & \multirow{3}{*}{$\begin{array}{r}1.215 \\
.994\end{array}$} & \multirow[t]{3}{*}{1.222} & \multirow[t]{3}{*}{.304} \\
\hline & Within Groups & 144.140 & 145 & & & \\
\hline & Total & 149.000 & 149 & & & \\
\hline \multirow{3}{*}{$\begin{array}{l}\text { Person * Years spent in } \\
\text { current organization }\end{array}$} & Between Groups & 4.162 & 4 & \multirow{3}{*}{$\begin{array}{r}1.040 \\
.999\end{array}$} & \multirow[t]{3}{*}{1.042} & \multirow[t]{3}{*}{.388} \\
\hline & Within Groups & 144.838 & 145 & & & \\
\hline & Total & 149.000 & 149 & & & \\
\hline
\end{tabular}

No variable is significant, Sig. $>0.1$ 
The conclusions that result from the application of the ANOVA analysis in relation to the variable years spent in current organization:

- Regardless of the types of cultures found within banking systems, there are no significant differences based on the years spent by employees in leadership positions within their current organization;

- Managers with very few years within the organization (between 0-5) and those with many years (over 20) tend to Disagree, while managers with between 10-15 years within their respective organizations tend on average to Agree.

(2) Centralization of Results Section 02

- The result of the correlations that exist between the types of organizational cultures and the variables considered - country of origin of the majority capital; age, level of professional experience within the banking system and years spent in the organization, both for respondents in leadership positions as well as operating personnel are illustrated and centralized in Table 9 and Table 10 and presented in detail in Annex 5

Table1. Influence of certain variables over organizational cultures - respondents in leadership positions

\begin{tabular}{|c|c|c|c|c|c|}
\hline $\begin{array}{l}\text { Types of } \\
\text { organizational } \\
\text { cultures }\end{array}$ & $\begin{array}{c}\text { Country of origin } \\
\text { for the majority } \\
\text { capital }\end{array}$ & Gender & Age & $\begin{array}{c}\text { Years in } \\
\text { organization }\end{array}$ & $\begin{array}{l}\text { Level of } \\
\text { professional } \\
\text { experience } \\
\text { within the } \\
\text { banking }\end{array}$ \\
\hline Task Type Culture & $\begin{array}{c}\mathrm{F}=5.708 \\
\text { Sig }=\mathbf{0 . 0 0 0}^{* * *}\end{array}$ & $\begin{array}{l}F=3.375 \\
\text { Sig }=0.068^{*}\end{array}$ & $\begin{array}{l}F=0.956 \\
\text { Sig }=0.416\end{array}$ & $\begin{array}{l}F=1.690 \\
\text { Sig }=0.155\end{array}$ & $\begin{array}{l}F=0.610 \\
\text { Sig }=0.656\end{array}$ \\
\hline Power Type Culture & $\begin{array}{l}F=7.611 \\
\text { Sig }=0.000 * * *\end{array}$ & $\begin{array}{l}F=2.337 \\
S i g=0.128\end{array}$ & $\begin{array}{l}F=0.236 \\
\text { Sig }=0.871\end{array}$ & $\begin{array}{l}F=1.222 \\
S i g=0.304\end{array}$ & $\begin{array}{l}F=0.606 \\
\text { Sig }=0.659\end{array}$ \\
\hline Role Type Culture & $\begin{array}{l}F=2.043 \\
\text { Sig = 0.054* }\end{array}$ & $\begin{array}{l}F=3.730 \\
\text { Sig }=0.055^{*}\end{array}$ & $\begin{array}{l}F=1.399 \\
\text { Sig }=0.245\end{array}$ & $\begin{array}{l}F=1.026 \\
\text { Sig }=0.396\end{array}$ & $\begin{array}{l}\mathrm{F}=2.566 \\
\mathrm{Sig}=\mathbf{0 . 0 4 1}\end{array}$ \\
\hline Person Type Culture & $\begin{array}{l}\mathrm{F}=2.213 \\
\text { Sig }=\mathbf{0 . 0 3 7}\end{array}$ & $\begin{array}{l}F=0.052 \\
S i g=0.820\end{array}$ & $\begin{array}{l}F=1.634 \\
\text { Sig }=0.184\end{array}$ & $\begin{array}{l}F=1.042 \\
\text { Sig }=0.388\end{array}$ & $\begin{array}{l}F=0.875 \\
\text { Sig }=0.481\end{array}$ \\
\hline
\end{tabular}

${ }^{*}$ lower significance level< $10 \%,{ }^{* *}$ average significance level< $5 \%,{ }^{* * *}$ high significance level- 1\%

Source: author's projection

(2) Centralization of results with respect to operational personnel

Table 2. Influence of certain variables over organizational cultures - operating personnel

\begin{tabular}{|c|c|c|c|c|c|}
\hline $\begin{array}{l}\text { Variables } \\
\begin{array}{l}\text { Types of } \\
\text { organizational } \\
\text { cultures }\end{array}\end{array}$ & $\begin{array}{c}\text { Country of } \\
\text { origin for the } \\
\text { majority capital }\end{array}$ & Gender & Age & $\begin{array}{c}\text { Years in } \\
\text { organization }\end{array}$ & $\begin{array}{c}\text { Level of } \\
\text { professional } \\
\text { experience } \\
\text { within the } \\
\text { banking } \\
\text { system }\end{array}$ \\
\hline Task Type Culture & $\begin{array}{c}\mathrm{F}=3.546 \\
\text { Sig }=\mathbf{0 . 0 0 1} \text { *** }\end{array}$ & $\begin{array}{l}F=3.156 \\
\text { Sig }=0.078^{*}\end{array}$ & $\begin{array}{l}F=1.236 \\
\text { Sig }=0.297\end{array}$ & $\begin{array}{l}\mathrm{F}=0.326 \\
\text { Sig }=0.861\end{array}$ & $\begin{array}{l}F=0.968 \\
\text { Sig }=0.426\end{array}$ \\
\hline Power Type Culture & $\begin{array}{l}\mathrm{F}=5.233 \\
\text { Sig = 0.000*** }\end{array}$ & $\begin{array}{l}F=2.200 \\
\text { Sig }=0.139\end{array}$ & $\begin{array}{l}\mathrm{F}=0.820 \\
\mathrm{Sig}=0.484\end{array}$ & $\begin{array}{l}\mathrm{F}=0.536 \\
\mathrm{Sig}=0.709\end{array}$ & $\begin{array}{l}F=1.190 \\
\text { Sig }=0.316\end{array}$ \\
\hline Role Type Culture & $\begin{array}{l}\mathrm{F}=3.416 \\
\text { Sig }=\mathbf{0 . 0 0 2} * * *\end{array}$ & $\begin{array}{l}F=1.237 \\
\text { Sig }=0.267\end{array}$ & $\begin{array}{l}F=1.326 \\
\text { Sig }=0.266\end{array}$ & $\begin{array}{l}\mathrm{F}=0.526 \\
\mathrm{Sig}=0.717\end{array}$ & $\begin{array}{l}F=1.827 \\
\text { Sig }=0.124\end{array}$ \\
\hline Person Type Culture & $\begin{array}{l}\mathrm{F}=4.925 \\
\mathrm{Sig}=\mathbf{0 . 0 0 0} * * *\end{array}$ & $\begin{array}{l}F=0.106 \\
\text { Sig }=0.745\end{array}$ & $\begin{array}{l}\mathrm{F}=0.126 \\
\text { Sig }=0.945\end{array}$ & $\begin{array}{l}\mathrm{F}=0.792 \\
\mathrm{Sig}=0.531\end{array}$ & $\begin{array}{l}F=0.496 \\
\text { Sig }=0.738\end{array}$ \\
\hline
\end{tabular}

* lower significance level< $10 \%,{ }^{* *}$ average significance level< $5 \%,{ }^{* * *}$ high significance level - 1\%

Source: author's projection

In what follows we have endeavored to illustrate the opinion of managers, considering the grouping of organizational cultures that are open to change, respectively the Task Types with the Power Types, as well as those that are reticent towards change, respectively the Role Types with the Person Types, starting from the differentiation of banks that they belong to, based on country of origin of the majority capital. Thus, the graphic representation of the answers is the following: 
Graph3. Opinion of managers regarding organizational cultures that are open to change vs. those that are reticent

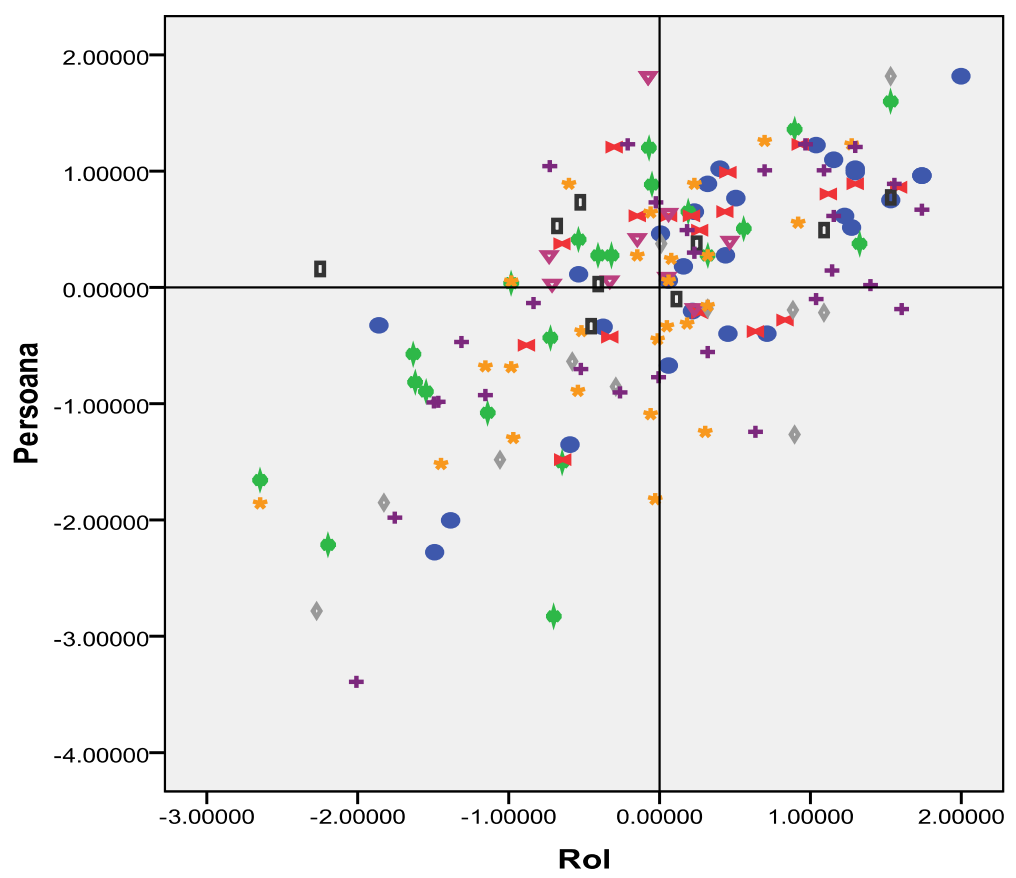

Tara de provenienta a capitalului majoritar

Romania Austria Aranta

$\checkmark$ Italia

$\nabla$ Olanda

* Grecia

Ungaria
+ Alte tari

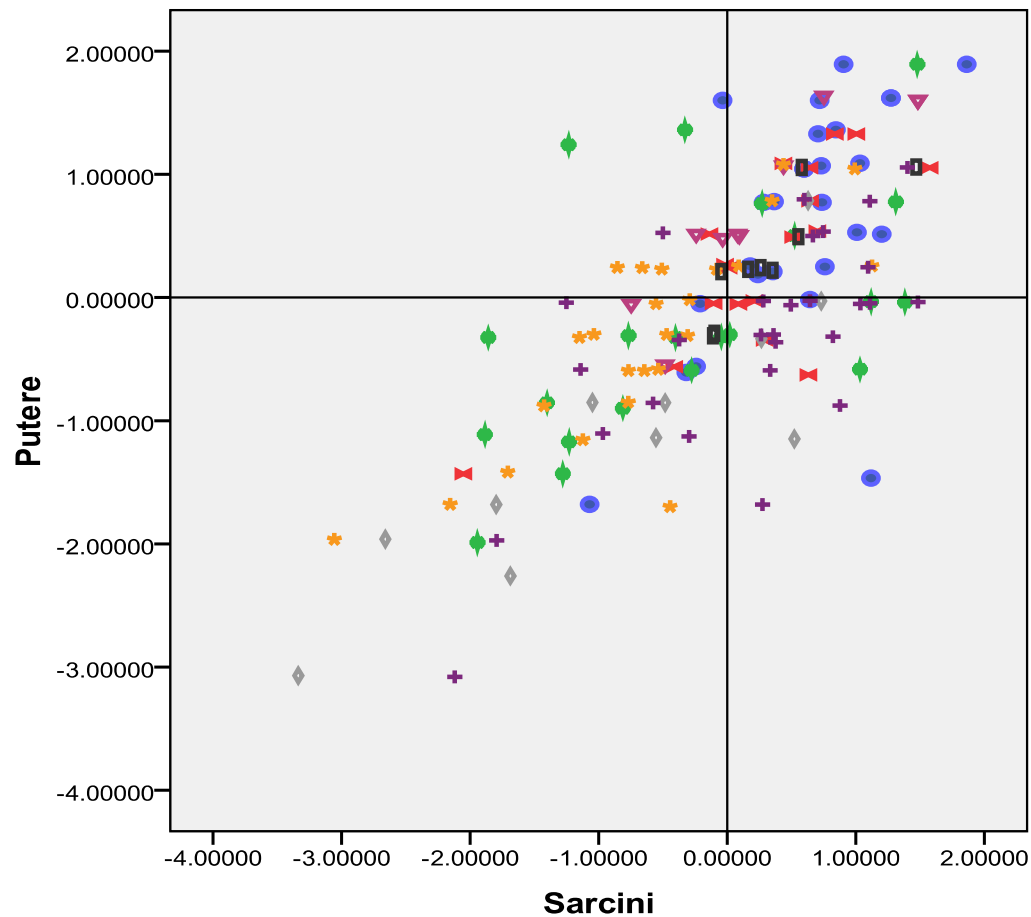

Tara de provenienta a capitalului majoritar

Romania * Austria

Franta

$\checkmark$ Italia

$\nabla$ Olanda

* Grecia

Ungaria

+ Alte tari

Source: author's projection

With respect to the opinion of operating personnel, considering the same grouping of organizational cultures mentioned, also in the case of managers, the graphic representation of the answers is the following: 
Graph 4. The opinion of operating personnel regarding organizational cultures that are open vs. reticentto change

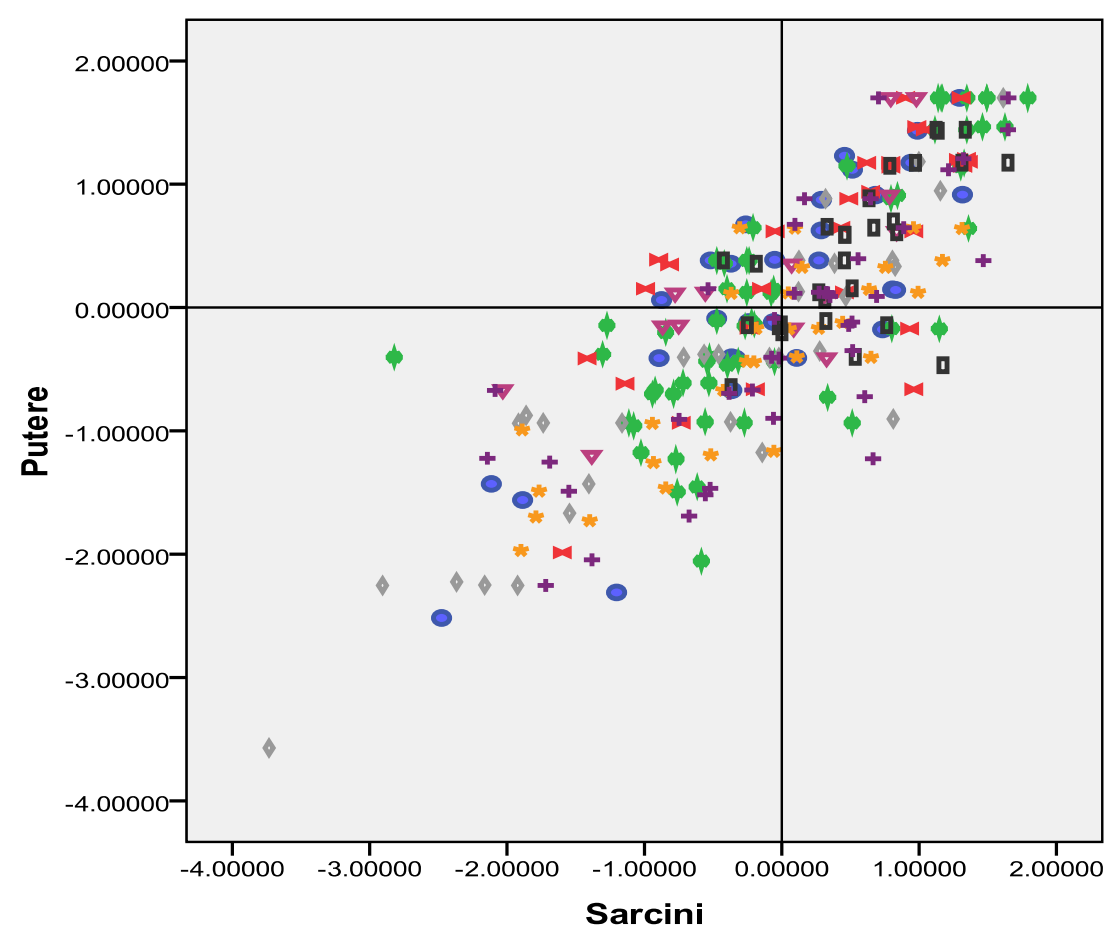

Tara de provenienta a capitalului majoritar

Romania
Austria
Franta
Italia
$\nabla$ Olanda
* Grecia
Ungaria
+ Alte tari

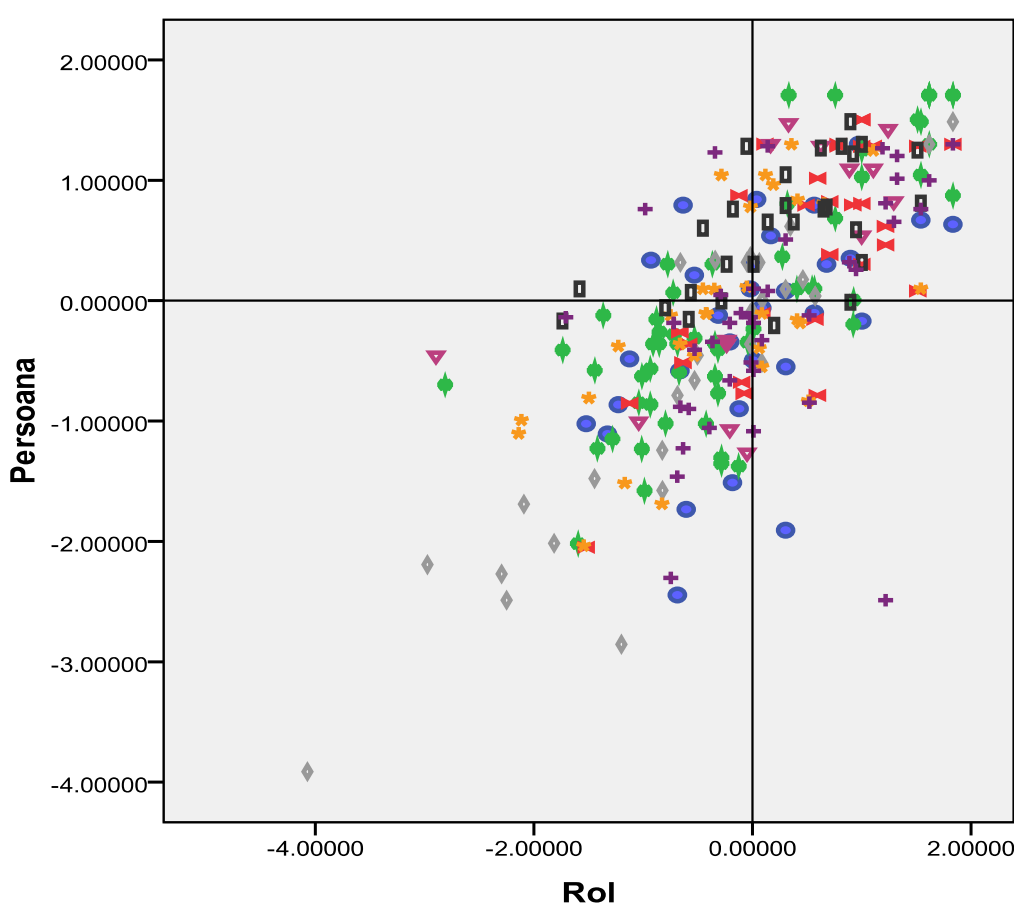

Tara de provenienta a capitalului majoritar

Romania

Austria

Aranta

$\checkmark$ Italia

$\checkmark$ Olanda

* Grecia

Ungaria

+ Alte tari

\section{Conclusions}

Source: author's projection

Based on the analysis of what has been presented, we can affirm the following:

- The country of origin of the majority capital influences the organizational culture of the Romanian banking system, regardless of the type of culture found, both with regard to operational personnel as well as managers;

- For both categories of employees, age and years spent in the organization do not influence organizational culture, irrespective to the type of culture that manifests itself;

- Neither does experience within the banking system manifest itself as a variable with an impact on the organizational culture, with the exception of banks in which the Role Type culture predominates and in which managers are aware of the importance of aquired experience in the domain; 
- Gender has an impact on the Task Type organizational culture both with respect to operational personnel as well as those in leadership positions, the influence being nevertheless of little significance.

- With respect to the opinion of those interviewed regarding the organizational cultures that are open to change, respectively the Task Type with the Power Type, and to the ones that are reticent to change, respectively the Role Type with the Person Type, starting from the differentiation of the banks they carry out their activities, based on the country of origins of the majority capital we can conclude the following:

- Managers that work in banks with a Romanian majority capital, irrespective of the organizational cultures that are manifested, they are in agreement with these, with a more prolific tendency in the case of those open to change;

- On the other end of the spectrum, managers from banks with an Italian majority capital, regardless of the organizational cultures manifested, are opposed to them, with a greater degree in the case of those that are favorable to change;

- In the context of some organizational cultures open to change, managers from banks with a Greek majority capital tend to disagree, unlike those from banks with a Hungarian majority capital who tend to agree;

- A tendency emerges from managers of banks with a French majority capital towards agreement, especially in the case of organizational cultures that are reluctant to change; while managers from an Austrian majority capital tend towards disagreement, especially within organizational cultures that are favorable to change.

- With respect to the opinions of operational personnel we may conclude the following:

- As in the case of managers, operational personnel from banks with a Romanian majority capital also tend to agree, but less so than them, and in the case of organizational cultures that are reluctant to change, one may observe a tendency towards reversing the convergence;

- Operating personnel from banks with an Italian majority capital tend to disagree, a fact that is seen also in the case of banks with an Austrian majority capital, but to a lesser degree;

- Regardless of the predominant organizational culture, operating personnel from banks with a Hungarian majority capital tend to agree;

- In the context of organizational cultures that are open to change, operating personnel that belong to banks with a Greek majority capital, tend to disagree, an aspect which is evident also in the case of managers from within the same institution;

- In banks with a French majority capital, with respect to operating personnel, the tendency is towards agreement, especially in the case of organizational cultures that are reluctant to change.

Summing up the above statements, we can affirm that by identifying the correlation that exists between the types of organizational cultures and the country of origin of the majority capital, the gender of the employees, their age, their level of professional experience within the banking system and the years spent within the same organization of the respondents, we can establish the directions to be followed in order to raise awareness of the importance of knowledge regarding the organizational culture.

\section{References}

1. Cristache $N$, Nastase M, Petrariu R, Florescu M., Analysis of congruency effects of corporate responsibility code implementation on corporate sustainability in bio-economy, Revista Amfiteatru Economic, ISSN: 1582 - 9146, vol. 21, Issue: 52, aug 2019

2. Handy, C. B. (1985), Understanding Organizations, Penguin Books

3. Hofstede, G., Hofstede, G. J., Minkow, M. (2012), Culturi și Organizații. Softul Mental: Cooperarea Interculturală și Importanța ei pentru Supraviețire, Editura Humanitas, București

4. Lynch, R. (2002), Strategia Corporativă, Editura ARC, Chișinău

5. Marcoulides, G. A., Heck, R. H. (1993), Organizational Culture and Performance: Proposing and Testing a Model, Organizational Science, vol. 4, issue 2, p.209-225

6. Peters, T. J., Waterman, R. H. (1982), In Search of Excellence: Lessons from America's Best-Run Companies, Harper \& Row

7. Schein, E. H. (1985), Organizational Culture and Leadership, University of Illinois at Urbana-Champaign's Academy for Entrepreneurial Leadership Historical Research Reference in Entrepreneurship

8. Zheng, X., El Ghoul, S., Guedhami, O., Kwok, C. C. Y. (2012), National Culture and Corporate Debt Maturity, Journal of Banking \& Finance, vol. 36, issue 2, p.468-488 